\title{
Hyperosmolar non-ketoacidotic coma as a complication of cerebral compression
}

\author{
A. R. DAVIDSON* \\ M.R.C.P. \\ Frenchay Hospital, Bristol
}

HyPerosmolar non ketoacidotic diabetic coma was first described in 1957 by de Graeff \& Lips and by Sament \& Schwartz and since then well over 100 cases have been recorded (Spenney, Eure \& Kreisburg, 1969). This condition is probably more common than first expected (de Graeff, 1963). The main features of the disorder are severe hyperglycaemia, hyperosmolarity and dehydration in the absence of ketosis; it is difficult to recognize because of the absence of the classical signs of hyperventilation and the smell of ketones on the breath. It tends to occur in older patients in previously unrecognized diabetics. Focal seizures are known to occur (Maccario, Messis \& Vastola, 1965) in some cases, even when no other intracranial condition is present to account for them.

Two cases are recorded here of hyperosmolar nonketoacidotic diabetic coma (Table 1), occurring in patients following cerebral compression, both of whom had focal fits.

\section{Case 1}

A man of 63 years with no previous family history of diabetes, was admitted with unsteadiness of gait and a right-sided deafness for 1 year, and vertigo and tinnitus for 1 month. Examination showed signs suggestive of a right posterior fossa space-occupying lesion, with total right-sided deafness and absent caloric reaction on the right side. His urine was free of sugar.

A myodil ventriculogram showed a massive shift

* Present address: St Mary's General Hospital, Milton, Portsmouth. of the fourth ventricle and aqueduct to the left. Following this he had a right temporal craniotomy and transtentorial removal of a large acoustic neuroma. The initial post-operative recovery was good, but after 2 days he began to deteriorate. By the twelfth postoperative day he had developed signs of cerebral compression. A right carotid arteriogram now showed an extradural haematoma lying under the bone flap; this was evacuated through a burr hole. This made little difference to his condition and his conscious level continued to deteriorate. Four days later the craniotomy was reopened and residual clot removed completely. Again, little improvement followed. One day after the further operation he began to have left-sided fits, partly controlled at first with phenobarbitone and diphenylhydantoin. Two days later the fits were not controlled and diazepam and paraldehyde were added.

He was then discovered to have heavy glycosuria and a urinary output which exceeded his intake by over a litre in $24 \mathrm{hr}$. His blood sugar was $790 \mathrm{mg} / 100$ $\mathrm{ml}$, the blood urea $100 \mathrm{mg} / 100 \mathrm{ml}$ and the serum sodium $160 \mathrm{mEq} / 100 \mathrm{ml}$. The serum osmolality was $381 \mathrm{mOsm} / \mathrm{kg}$ as calculated by the method of Scott (Nicholson et al., 1964). He was given 40 Units of insulin intravenously and $\mathbf{4 0}$ Units by intramuscular injection. One litre of 1/6 molar lactate was given in $2 \mathrm{hr}$. The blood pressure fell to a systolic level of 60 $\mathrm{mmHg}$ and he developed Cheyne-Stokes respiration. This responded dramatically to the intravenous infusion of 2 pints of blood in half-an-hour.

TABLE 1.

\begin{tabular}{llcc}
\hline & & Case 1 & Case 2 \\
\hline Blood sugar & $(\mathrm{mg} / 100 \mathrm{ml})$ & 790 & 680 \\
Blood urea & $(\mathrm{mg} / 100 \mathrm{ml})$ & 101 & 158 \\
Serum sodium & $(\mathrm{mEq} / \mathrm{l})$ & 160 & 161 \\
Serum potassium & $(\mathrm{mEq} /)$ & $3 \cdot 4$ & $4 \cdot 2$ \\
Serum chloride & $(\mathrm{mEq} / \mathrm{l})$ & 119 & 118 \\
Osmolality & $(\mathrm{mOsm} / \mathrm{kg})$ & 381 & 386 \\
Po $_{2}$ & $(\mathrm{~mm})$ & - & 100 \\
Pco $_{2}$ & $(\mathrm{~mm})$ & 38 & 33 \\
pH & & $7 \cdot 37$ & $7 \cdot 45$ \\
Fluid given (litres) & & $14 \mathrm{in} 48 \mathrm{hr}$ & $4 \mathrm{in} 24 \mathrm{hr}$ \\
Insulin given (Units) & & $306 \mathrm{in} 16 \mathrm{hr}$ & $120 \mathrm{in} 24 \mathrm{hr}$ \\
Diabetic control & & $2000 \mathrm{calorie}$ diet & Chlorpropamide 250 mg/da: \\
\hline
\end{tabular}


He needed a total of 305 Units of insulin in 16 $\mathrm{hr}$ to bring his blood sugar to normal, 14 litres of fluid and $100 \mathrm{mEq}$ of potassium to restore his electrolytes to normal. His epileptic fits disappeared without further treatment.

Following this he made a slow but steady recovery, and was discharged from hospital 40 days later. The diabetes was controlled by diet alone.

\section{Case 2}

A woman of 64 years who had had on one occasion glycosuria which was not investigated and needed no treatment, was admitted to another hospital, having slipped on the ice and sustained a head injury. She did not lose consciousness but vomited on several occasions. Over the following 6 days her level of consciousness deteriorated, but varied considerably. At the time of transfer she was deeply unconscious, but recovered slightly to enable a left hemiplegia to be diagnosed.

A right carotid arteriogram showed a large subdural haematoma which was evacuated by a right lateral craniotomy. After operation she improved in conscious level for $18 \mathrm{hr}$, but then became drowsy again. The craniotomy was reopened and a haematoma was removed. Again she improved, but 3 days after her second operation she developed left-sided epileptic convulsions. These were initially controlled with diazepam, but 2 days later they recurred. She had frequent convulsions, eleven in $24 \mathrm{hr}$, despite phenobarbitone, diphenylhydantoin and diazepam. Thiopentone was given by intravenous infusion and she was respired artificially. She was noted to have $1 \%$ glycosuria and the caloric intake at this stage was in excess of 2500 calories per day. This intake was reduced, but on the following day her blood sugar was $680 \mathrm{mg} / 100 \mathrm{ml}$, the blood urea was $158 \mathrm{mg} / 100$ $\mathrm{ml}$, the serum sodium $161 \mathrm{mEq} / 100 \mathrm{ml}$ and the serum osmolality $386 \mathrm{mOsm} / \mathrm{kg}$.

She was given 50 Units of soluble insulin immediately and her fluid intake was increased to 4 litres in $24 \mathrm{hr}$. She needed 120 Units of insulin to bring her blood sugar to normal. Her convulsions had disappeared $24 \mathrm{hr}$ later. Her insulin requirements were gradually reduced as her mental state improved. Her recovery was prolonged but she regained full consciousness after 1 month and was discharged from hospital 2 months after operation. At the time of discharge her diabetes was well controlled with chlorpropamide $250 \mathrm{mg}$ /day.

\section{Discussion}

Patients with hyperosmolar non-ketoacidotic coma usually present with an insidious onset over several days or weeks, the sequence of events being polyuria, low fluid intake, although rarely with polydypsia, followed by profound dehydration, marked con- fusion, stupor and coma. In most cases there is no previous history of diabetes, which is of adult onset type. It is rare in younger people with one exception in an 18-month-old child (Ehrlich \& Bain, 1967). The condition is often difficult to recognize clinically, as the usual signs of diabetic coma, namely hyperventilation and ketosis are absent. Some patients present with focal seizures (Maccario, 1969); these patients have no obvious cause for their seizures and in none is there gross structural brain disease. Both of the patients described developed their hyperosmolar non-ketoacidotic coma following severe cerebral compression, both were critically ill at the time of diagnosis and had seizures for $48 \mathrm{hr}$. In each the seizures were referable to the cerebral hemisphere underlying the clot.

Hyperosmolar non-ketoacidotic diabetic coma has been reported with acute pancreatitis (Davidson, 1964; Halmos, 1966), carcinoma of the pancreas (Jackson \& Forman, 1966), following dialysis (Boyer, 1967), following severe burns (Bailey, 1966; Rosenburg et al., 1965), in patients treated with steroids (Boyer, Gill \& Epstein, 1967; Kumur, 1968; Pyorala, Suhonen \& Pentikainon, 1968; Spenney et al., 1969), and in patients following the administration of diphenylhydantoin (Goldberg \& Sanbar, 1969). There are no cases described in association with cerebral compression, although glycosuria is found in about $30 \%$ of patients following severe head injury; a few of these also have hyperglycaemia (Higgins et al., 1954).

Several theories have been put forward as to why these patients do not develop ketosis. In some there may be a definite lactic acidosis (Danowski \& Nabarro, 1965), but it is not constantly found. Tissue anoxia is probably responsible when it occurs. Some cases occur with renal disease without ketonuria but with detectable serum ketone levels (Danowski \& Nabarro, 1965). Recently it has been shown that the plasma insulin levels in one of these patients were raised (Johnson et al., 1969). These authors believe that there is persistence of enough insulin production to prevent ketoacidosis, but a very severe suppression of insulin release in relation to the level of blood glucose.

The early diagnosis of this condition is vital; delay may be fatal. The aim of treatment is rehydration and a decrease in blood sugar. There is considerable controversy over exactly which fluid is best for the purpose (Sament, 1966; Faegin, 1966; Rosen $\&$ Glick, 1966). Five percent dextrose may be used providing it is accompanied by sufficient insulin to stop any further rise in blood sugar, therefore stopping the diuresis. Physiological saline is hypotonic to the patient's serum and its use is therefore justified. Probably no hard and fast rules can be laid down for the management of this condition (Watson, 1966). 
Some patients have been treated successfully with physiological saline until the blood sugar fell and then with $4.3 \%$ dextrose saline (Martin, 1968).

Recently hypotonic fructose has been suggested as as initial treatment (Johnson et al., 1969). Hypotension and circulatory collapse caused by severe dehydration must be treated with albumen, plasma or whole blood (Matz \& Drapkin, 1966) as in the first case reported here. Insulin should be given in adequate amounts frequently, depending on the blood sugar levels. Large quantities may not be needed; one reported case needed no insulin (Hayes \& Woods, 1968). Patients presenting with focal seizures are often treated with anticonvulsants; these are ineffective (Maccario et al., 1965) and diphenylhydantoin may be contraindicated (Goldberg \& Sanbar, 1969). These focal seizures are always controlled when the hyperosmolar diabetic state is corrected.

The prognosis is grave; a mortality of $50 \%$ has been recorded (Halmos, Nelson \& Lowry, 1966). This high mortality can only be reduced by early recognition and prompt treatment. The recognition may be difficult because of the lack of signs. Focal seizures following cerebral compression are common, but this condition should be suspected when the recovery is unduly prolonged despite relief of cerebral compression and when the seizures are not responding to conventional anti-convulsant therapy.

\section{Acknowledgments}

I am most grateful for the encouragement and assistance given to me by $\mathrm{Mr} \mathrm{H}$. B. Griffith and Mr D. G. Phillips in letting me publish their cases.

\section{References}

BAILEY, B.W. (1960) Hyperglycaemia in burns. British Medical Journal, 2, 1783.

Boyer, J., Gill, G.N. \& Epstein, F.H. (1967) Hyperglycaemia and hyperosmolarity complicating peritoneal dialysis. Annals of Internal Medicine, 67, 568.

BOYER, M.H. (1967) Hyperosmolar anacidotic coma in association with glucocorticoid therapy. Journal of American Medical Association, 202, 1007.

DaNOWSKI, T.S. \& NabarRo, J.D.N. (1965) Hyperosmolar and other types of non ketoacidotic coma in diabetes. Diabetes, 14, 162.

Davidson, A.I.G. (1964), Diabetic coma without ketoacidosis in a patient with acute pancreatitis. British Medical Journal, 1, 356.
DE GRAFFF, J. \& L.IPS, J.B. (1957) Hypernatraemia in diabetes mellitus. Acta Medica Scandinavica, 157, 71.

DE GraefF, J. (1963) Diabetic coma without ketoacidosis. (Correspondence). Lancet, i, 1322.

Ehrlich, R.M. \& BaIN, H.W. (1967) Hyperglycaemia and hyperosmolarity in an eighteen month old child. New England Journal of Medicine, 276, 683.

FAEGIN, O.T. Hyperosmolar coma in diabetes. (Correspondence). Lancet, ii, 51.

Goldberg, E.M. \& Sanbar, S.S. Hyperosmolar non ketotic coma following the administration of Dilantin (diphenylhydantoin). Diabetes, 18, 101.

Halmos, B.P. (1966) Hyperosmolar non ketoacidotic diabetic coma in a patient with nectotizing pancreatitis. British Medical Journal, 2, 685.

Halmos, P.B., Nelson, J.K. \& Lowry, R.C. (1966) Hyperosmolar non ketotic coma in diabetes. Lancet, i, 675.

HaYes, T.M. \& Woods, C.F. (1968) Hyperosmolar non ketotic coma. (Correspondence). Lancet, i, 209.

Higgins, G., Lewin, W., O'Brien, J.R.P. \& TAYLor, W.H. (1954) Metabolic disorders of head injury. Lancet, $\mathbf{i}, 61$.

JACKSON, W.P.U. \& FORMAN, R. (1966) Hyperosmolar non ketotic diabetic coma. Diabetes, 15, 720.

Johnson, R.D., Conn, J.W., Dykman, C.J., Pek, S. \& STARR, J.I. (1969) Mechanisms and management of coma with ketoacidosis in the diabetic. Diabetes, 18, 111.

KUMUR, R.S. (1968) Hyperosmolar non ketotic coma. (Correspondence). Lancet, i, 48.

Maccario, M., Messis, C.P. \& Vastola, E.F. (1965) Focal seizures as a manifestation of hyperglycaemia without ketoacidosis. Neurology, 15, 195.

MARTIN, A. (1968) Hyperosmolar non ketoacidotic diabetic coma. Postgraduate Medical Journal, 44, 218.

MATZ, R. \& DRAPKIN, A. (1966) Hyperosmolar coma in diabetes. (Correspondence). Lancet, i, 1001.

Nicholson, W.A., Shujuauddin, Pattel, W.T. \& Scotr, W.J. Diabetic coma without ketoacidosis. Lancet, i, 982.

Pyorala, K., Suhonen, O. \& Pentikainen, P. (1968) Steroid therapy and hyperosmolar non ketotic coma. (Correspondence). Lancet, i, 596.

ROSEN, H. \& Glick, S.M. (1961) Hyperosmolar coma. (Correspondence). Lancet, i, 1101.

Rosenberg, S.A., Brief, D.K., Kinney, J.M., Herrer, M.G., Wilson, R.E. \& MOORE, F.D. (1965) The syndrome of dehydration, coma, severe hyperglycaemia without ketosis in patients convalescing from burns. New England Journal of Medicine, 272, 931.

Sament, S. \& Schwartz, M.D. (1957) Severe diabetic stupor without ketosis. South African Medical Journal, 31, 893 .

Sament, S. (1966) Hyperosmolar coma in diabetics. (Correspondence). Lancet, i, 1153.

Spenney, J.G., Eure, C.A. \& Kreisberg, R.A. (1969) Hyperglycaemic hyperosmolar non ketotic diabetes a complication of steroid and immunosuppressive therapy. Diabetes, 18, 107.

WATSON, J.V. (1966) Hyperosmolar diabetic coma. (Correspondence). Lancet, ii, 278. 